\title{
Usage of Tax Saving Instruments Among Individual Assesses
}

\author{
Srinidhi P, Khavi Priya B
}

\begin{abstract}
Tax planning is one of the key aspects of financial planning from a tax perspective. Efficient tax planning enables every taxpayer to reduce the tax liability to the minimum. This is done by legitimately availing various tax exemptions, deductions under chapter VIA, rebates and allowances available under the Income Tax Act, 1961. The ever increasing functions of the government have naturally lead to increased expenditure, for instance, achieving the social and economic objectives laid down in the constitution, balancing regional economic growth, removing the concentration of economic power in few hands, reducing the inequality of income, and so on. The wealth of an individual is maximized by increasing the level of savings in various investment avenues. The key area of the research is to learn the appropriate popularly used tax saving instruments and also the factors influence the investment in those tax saving instruments. It is empirical research which will throw light upon the aspects of tax planning and ways to reduce the income tax liability.
\end{abstract}

Keywords : Tax-saving instruments, tax planning, deductions, and the individual assessee.

\section{INTRODUCTION}

$\mathrm{T}_{\mathrm{h}}$ he term tax may be defined as a compulsory extraction made by the Central Government from the general public. It is a financial charge imposed on individuals by the Government under its legislative authority. It is not a voluntary donation or payment, but an enforced contribution exacted pursuant to legislative authority. Income is a periodical return with the regularity or expected regularity and that refers to only monetary returns. It also includes loss and represented as negative income to set off or adjusting in the positive income. The Income Tax Act has defined the term income and it includes income from salary, income from house property, profits and gains from business or profession, capital gains and income from other sources. There are certain incomes are specifically exempt (uls 10) from income tax like agriculture income, awards instituted by the government, leave travel concession, etc.,

GROSS TOTAL INCOME = Income from salary + Income from House property+ Profits and Gains from Business or Profession + Capital gains + Income from Other Sources

TAX PLANNING: It is the action undertaken by the

Revised Manuscript Received on December 05, 2019.

* Correspondence Author Devkunvar Nanalal Bhatt Vaishnav College for Women, Chennai, Tamil Nadu, India, Email: padhuvimi.nithi@gmail.com

Khavi Priya B, Student, M.Com Accounting and Finance, Shrimathi Devkunvar Nanalal Bhatt Vaishnav College for Women, Chennai, Tamil Nadu, India, Email: khavipriya12@gmail.com
Srinidhi P*, Student, M.Com Accounting and Finance, Shrimathi

assessee to reduce the tax liability to a minimum by making the optimum use of permissible deductions, allowances, and exemptions.

TAX EVASION: Deliberate reduction in Income earned or increase in Expenditure.

Income Tax Deductions for FY-2018-19, Tax deduction limits under few Sections of the Income Tax Act, 1961 is given below:

\begin{tabular}{|c|c|}
\hline $\begin{array}{l}\text { Under Section } \\
\qquad 80 \mathrm{C}\end{array}$ & $\begin{array}{l}\text { 1. Provident fund } \\
\text { 2. Post office savings scheme } \\
\text { 3. LIC insurance plan } \\
\text { 4. NSC bonds } \\
\text { 5. Equity-linked saving scheme } \\
\text { 6. General insurance plan } \\
\text { 7. Mutual funds } \\
\text { 8. Senior citizen saving scheme } \\
\text { 9. ULIPs }\end{array}$ \\
\hline $\begin{array}{l}\text { Under Section } \\
\qquad 80 \mathrm{CC}\end{array}$ & Contribution to LIC pension scheme \\
\hline $\begin{array}{l}\text { Under Section } \\
\text { 80CCD }\end{array}$ & Employee contribution to government pension schemes \\
\hline $\begin{array}{l}\text { Under Section } \\
\qquad 80 \mathrm{D}\end{array}$ & $\begin{array}{l}\text { 1. Health insurance premium } \\
\text { 2. Preventive health check-up }\end{array}$ \\
\hline $\begin{array}{l}\text { Under Section } \\
\text { 80DD }\end{array}$ & Spending on medical treatment \\
\hline $\begin{array}{l}\text { Under Section } \\
\text { 80DDB }\end{array}$ & $\begin{array}{l}\text { Expenditure on critical disease claimed by senior } \\
\text { citizens }\end{array}$ \\
\hline $\begin{array}{l}\text { Under Section } \\
\qquad 80 \mathrm{E}\end{array}$ & Expenditure on interest payable for Educational loan \\
\hline $\begin{array}{l}\text { Under Section } \\
\text { 80EE }\end{array}$ & Repayment of the principle amount of housing loan \\
\hline $\begin{array}{l}\text { Under Section } \\
\text { 24(B) }\end{array}$ & Interest paid on housing loan \\
\hline $\begin{array}{l}\text { Under Section } \\
\qquad 80 \mathrm{G}\end{array}$ & Contribution to a charitable trust and relief funds \\
\hline $\begin{array}{l}\text { Under Section } \\
87 \mathrm{~A}\end{array}$ & Tax rebate \\
\hline $\begin{array}{l}\text { Under Section } \\
\text { 80TTA }\end{array}$ & Interest on deposits from the saving account \\
\hline $\begin{array}{l}\text { Under Section } \\
\quad 80 \mathrm{U}\end{array}$ & Medical expenses for a disabled persons \\
\hline
\end{tabular}

Public Provident Fund: PPF can be opened in the name of an assessee, his /her spouse or their children, where the amount deposited by the assessee shall qualify for the tax deduction.

LIC Insurance Policy: Actual amount of premium deposited by the assessee or on his behalf by his employer or $10 \%$ of the sum assured value whichever is less shall qualify for the tax deduction. 
ULIPs: Any amount deposited by the assessee in Unit Linked Insurance Plan of UTI or LIC mutual fund shall fully qualify for the tax deduction.

NSC Bonds: Amount invested in National Savings Certificates -VIII or IX issue fully qualifies for the tax deduction.

Mutual Funds: Amount paid to the subscription to any mutual fund units, notified by CBDT shall be qualified for the tax deduction.

Senior Citizen Saving Scheme: It is not taxable by the legal heirers when it is withdrawn by them. It can claimed by senior citizens when they save their money under this scheme.

Deposit Scheme of Central Government: Any subscription to any such security of the Central Government or any such deposit scheme as Central Government may notify in Official Gazette, specifying in this behalf, will qualify for the tax deduction.

Equity-Linked Saving Scheme: Any amount invested in equity-linked saving scheme qualifies up to the actual amount invested. In case of the rebate, u/s 88 shall also qualify for the deduction.

Deposit in Saving Scheme: Actual amount of interest or Rs. 10000 whichever is less is the allowable tax deduction.

\section{OBJECTIVES OF THE STUDY}

- To study individual tax planning.

- To study about the usage of the tax-saving instruments among the individual assesses.

\section{RESEARCH METHODOLOGY}

No of Respondents: 100 respondents

Data Collection: Primary data collection - questionnaire Analysis:

The tools used for analysis are:

1. Cross tabulation

2. Percentage analysis

3. Factor analysis

4. Correlation analysis

\section{RESULTS AND DISCUSSION}

The following shows the cross values for Taxpayers and Occupation

Table - 1: Cross Tabulation between Taxpayers and Occupation

\begin{tabular}{|c|c|c|c|}
\hline \multirow{2}{*}{ Occupation } & \multicolumn{2}{|c|}{ Taxpayers } & \multirow{2}{*}{ Total } \\
\cline { 2 - 4 } & Yes & No & 1 \\
\hline Advocate & 0 & 1 & 3 \\
\hline Apprentice & 3 & 0 & 1 \\
\hline Consultant & 1 & 0 & 54 \\
\hline Private concern & 24 & 30 & 2 \\
\hline Public concern & 0 & 2 & 14 \\
\hline Entrepreneurship & 8 & 6 & 21 \\
\hline Profession & 18 & 3 & \\
\hline
\end{tabular}


Table - 3: Factor Analysis - Socio-Economic Factors - Total Variance Explained

\begin{tabular}{|c|c|c|c|c|c|c|c|c|c|}
\hline \multirow{2}{*}{ FACTORS } & \multicolumn{3}{|c|}{ Initial Eigenvalues } & \multicolumn{3}{|c|}{$\begin{array}{c}\text { Extraction Sums of Squared } \\
\text { Loadings }\end{array}$} & \multicolumn{3}{|c|}{ Rotation Sums of Squared Loadings } \\
\hline & Total & $\begin{array}{c}\% \text { of } \\
\text { Variance }\end{array}$ & $\begin{array}{c}\text { Cumulative } \\
\%\end{array}$ & Total & $\begin{array}{c}\% \text { of } \\
\text { Variance }\end{array}$ & $\begin{array}{c}\text { Cumulative } \\
\%\end{array}$ & Total & $\begin{array}{c}\% \text { of } \\
\text { Variance }\end{array}$ & $\begin{array}{c}\text { Cumulative } \\
\%\end{array}$ \\
\hline 1 & 2.153 & 43.050 & 43.050 & 2.153 & 43.050 & 43.050 & 1.687 & 33.748 & 33.748 \\
\hline 2 & 1.036 & 20.712 & 63.762 & 1.036 & 20.712 & 63.762 & 1.501 & 30.014 & 63.762 \\
\hline
\end{tabular}

Table - 4: Factor Analysis - Socio-Economic Factors Factor Matrix

\begin{tabular}{|l|c|c|}
\hline \multirow{2}{*}{ Socio Economic Factors } & \multicolumn{2}{|c|}{ Component } \\
\cline { 2 - 3 } & 1 & 2 \\
\hline $\begin{array}{l}\text { It strengthens my ability to use the financial resources } \\
\text { efficiently }\end{array}$ & .825 & \\
\hline It creates a sense of confidence about the future & .727 & \\
\hline $\begin{array}{l}\text { The financial strength on the account of savings and } \\
\text { investment gets me a social recognition }\end{array}$ & .644 & \\
\hline It enables me to invest in gold or precious ornaments & .566 & .648 \\
\hline I invest for the purpose of availing tax exemptions & & -.557 \\
\hline
\end{tabular}

Inference: The factor "It strengthens my ability to use the financial resources efficiently" was considered to be a primary factor that influences the socio-economic factor of tax planning.

Table - 5: FSocio-Economic Factors - Correlation Matrix

\begin{tabular}{|c|l|c|c|}
\hline \multicolumn{2}{|l|}{} & Instruments & Source \\
\hline \multirow{4}{*}{ Instruments } & Pearson Correlation & 1 & .105 \\
\cline { 2 - 4 } & Sig. (2-tailed) & & .298 \\
\cline { 2 - 4 } & $\mathrm{N}$ & 100 & 100 \\
\hline \multirow{3}{*}{ Source } & Pearson Correlation & .105 & 1 \\
\cline { 2 - 4 } & Sig. (2-tailed) & .298 & \\
\cline { 2 - 4 } & $\mathrm{N}$ & 100 & 100 \\
\hline
\end{tabular}

Inference: From the above table, it is inferred that the tax-savings instruments preferred by the respondents are positively correlated with their source of income.

\section{KEY RESEARCH FINDINGS}

- Nearly $68.2 \%$ of respondents feel that the existing savings schemes are adequate.

- Nearly $41.2 \%$ of respondents choose medium-term investment ranging for more than 5 years.

- Nearly $49.4 \%$ of respondents consider that the increase in their salary income will lead to an increase in the size of savings.

- Nearly $70.6 \%$ of respondents contribute $25 \%$ of their income for savings in various financial instruments and tax-saving instruments.

- Nearly $40 \%$ of respondents invest in tax savings instruments for financial security.

- Nearly $52.9 \%$ respondent' s income fall in below INR 300000

\section{SUGGESTION AND CONCLUSION}

Based on the research, it is considered that investments in tax saving instruments are the best way to claim deductions As per the preference of usage of tax-saving instruments, many individuals choose to invest in provident fund and life insurance plans followed by bank deposits. It is clear from the study that the individual's tax strategies are directly related to their age and income. If the tax liability of the individual is lower, they may have more disposable income which they can use for savings and investment.

The tax system prevailing in the country plays a vital role in mobilizing savings by way of inculcating the habit of investment among individuals in different avenues. The individual must ensure that they plan accordingly at the beginning of the financial year so that the benefits of using the financial and tax-saving instruments may outweigh the cost associated with it. Tax planning does much more than only saving taxes. Smart planning with the appropriate tax-saving instrument adds value to the portfolio. Hence must make a wiser decision to avoid the last-minute rush for tax savings.

\section{REFERENCES}

1. The impact of income tax on savings and investment: A case study of the assessee. (n.d.). Indian Journal of Applied Research.

2. Assessment of individual income tax, tax planning and savings in India. (n.d.). IJCEM.

3. Income tax planning: a study of tax saving instruments. (n.d.). IJMSSR.

4. S, L. K. (n.d.). Tax saving scheme and tax-saving instruments of income tax in India. IJSRD.

5. P, J. V., B, N. D., undefined, P. G., \& undefined, R. P. (2018). Income Tax Law and Practice (46th ed.). New Delhi, Delhi: Kalyani Publishers.

\section{AUTHORS PROFILE}

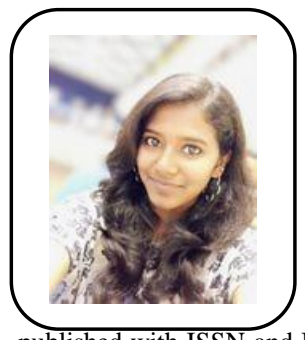

Khavi Priya Bagya Lakshmi is a unique author by nature having many accomplishments to her list. She hails from a commerce background making her one of the youngest budding author cum researcher of her domain in the country. She currently pursues ACCA, UK along with a Master's degree in Commerce from University of Madras, Chennai, India.She is passionate about Risk Management, Taxes, and Governance. Her write-ups include various journals and articles published with ISSN and ISBN. Her curiosity in research made her a default option for her college for inter-college paper presentations and demonstrations. "Constraints faced by SME in raising funds for financing" and "Forensic accounting in prevention of fraud" are a few of many worthy pieces of research of her to mention. She has a wide and long vision of educating herself by continuous learning and to others by sharing what is learned. She is commonly known as 'libree' (ack.Library bee) by her friends as she loves spending most of her time with books.Her passion doesn't stop with academics as she strives to 
pioneer in management skills, leadership skills, communication, and interpersonal skills. She loves to relax by Scuba diving and Indian classical dance.

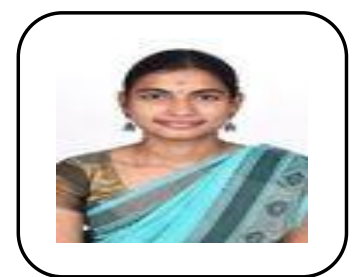

Srinidhi $\mathbf{P}$ is a young and zestful writer, orator and a researcher born and raised in Chennai, who is acclaimed for her paper presentations at various colleges and educational institutions across the country since 2015. Her thirst for becoming a well-known writer started at the age of 11 .

She currently pursues her Master of Commerce degree at SDNB Vaishnav College for Women, where she also did her Bachelor's degree. Her extensive list of literary works include articles published with International Standard Serial Number (ISSN) and journals in books with International Standard Book Number (ISBN). Srinidhi had also done many researches on diverse topics which includes, researches on the state-run transportation services and prospects and challenges faced by an auditor in a computerized environment. Srinidhi's interest to contribute to various journals at both national and international levels kicked off in 2015. Her achievements include 'The Rajya Puraskar' Award from the Governor of Tamil Nadu in 2014. Her proficiency in multiple disciplines landed her the 'Overall Champion' award at her school in 2010, 2012 and 2014. 